\title{
DEVELOPING AN INTERACTIVE MULTIMEDIA OF EMERGENCY STRETCHER SUBJECT IN EXTRACURRICULAR ACTIVITIES OF SCOUTING FOR HEARING IMPAIRMENT STUDENTS ON SPECIAL EDUCATION SENIOR HIGH SCHOOL
}

\author{
Muhamad Izhar Safawi ${ }^{a}$, Sihkabuden ${ }^{b}$ \\ ${ }^{a b}$ Department of Special Education, State University of Malang, Indonesia \\ E-mail: muhamad.izhar93@gmail.com
}

\begin{abstract}
Students with hearing impairment have hearing obstacle bringing complex impact, especially for the intellectual nuisance and communication obstacle that related to language and vocabulary. The purposes of this development was producing an interesting of multimedia interactive materials of emergency stretcher for students with hearing impairment. Method that use on this research and development was adapted from Borg and Gall (1989) models. The results showed that product was valid. The research results from material expert was obtained score $91 \%$ (very feasible), media expert $98 \%$ (very feasible), practitioner $84.5 \%$, the results of small group test was divided into two phases. They were phase I, learning with the help and guidance of teachers or coaches was obtained score $89.9 \%$ with the criteria of highly effective. Phase II, learning without the help and guidance of teachers or coaches was obtained score $75.8 \%$ with the criteria of effective and could be used according to a small group test. The results showed that product was valid, very decent and very effectively used with help and guidance teachers or coaches. The conclusion of this research was resulting a product including with criteria of being good and could improve cognitive abilities students with hearing impairment.
\end{abstract}

Keywords: multimedia interactive, scouting, hearing impairment.

Education is expected and emphasized not only given to those who have normal conditions, but also given to those who experience barriers or better known as children with special needs (ABK). According Somantri (2012: 93) hearing impairment is hearing loss that effected of a person can not make an expression a variety of stimuli, especially through the sense of hearing. Disruption to children with hearing loss in the cause delays in language development in children with hearing impairment. The language used to communicate with others and provide ease of deaf children to interact with the environment of the community.

Right to education for children with the disorder or with the barriers described in the law number 20 Year 2003 on National Education System Article 32, states that "special education is an education for students who have difficulty in following the learning process because of physical disorders, emotional, mental and social" (Effendi, 2009: 1). Based on the foundation of the law, it was concluded that all without exception in obtaining appropriate education to children with special needs including the potential of students with hearing impairment are entitled to a decent education in helping growth and development of students. Whether it's in terms of academic education and in terms of character education that is also useful for students from all walks of public life.
In Permendikbud number $81 \mathrm{~A}$ in 2013, about Implementation curriculum, in chapter VI, declared "in Curriculum 2013, Scouting defined as extra-curricular activities compulsory from elementary school (SD / $\mathrm{MI}$ ) to high school (SMA), in education from primary school to school upper middle class. Implementation can cooperate with local scouting organization or nearby". From the above explanation can be understood that the education activities of scouting is a very important activity for the development of student character. Including students with special needs, particularly the students with hearing impairment.

Scouting provides a very complex moral education, which is necessary for students to be able to better social live, not least for children with special needs, particularly the students with hearing impairment. Activities in Scouting is an activity in which emphasizes non-formal education also support formal education in schools and informal education in the family, in the form of student character development. The character development is carried out in a variety of activities and learning that is inside the scouting activities and education, through various media that supports the achievement of the objectives of the implementation of activities.

Based on observations in the field and the results of the needs analysis in the field, explains that during 
this learning Scouting can not be said to be effective in achieving its goals. As the data obtained, that extracurricular activities Scouting is not repeated during one school year, a lack of teachers or scoutmaster, lack of time allocated for the implementation of lesson hours Scouting extracurricular activities, as well as use of simple learning media.

The learning process students with hearing impairment there are some drawbacks, ranging from the characteristics of students who are different, the perception of understanding of students with hearing impairment different to what is delivered by teachers or coaches, students do not focus in learning due to the use of media that is less than the maximum and there is interference from the surrounding environment, thus interfere with the learning process and the achievement of learning objectives.

Scouting extracurricular activities at the school have been inactive for one school year, with material that was never delivered, such as marching, simple songs, ropes, setting up tents, make a stretcher, semaphore and morse. Based on a variety of information that has been presented, the teacher and the school stating the need for the development of interactive multimedia in extracurricular activities Scouting for students with hearing impairment. Researchers chose the material emergency stretcher to initiate reactivation extracurricular activities Scouting in SMALB BC Kepanjen, in this case as a research location.

Multimedia with various advantages, ranging from the high of student attractiveness, foster creativity, can be validated properly, there is stimulation and responses that support learning, able to motivate the students, is able to provide a good experience and accurate visualization, and interactive multimedia is easy to operate. Thus the development of technology-based which in this case is necessary so that the interactive multimedia needs were catered for in the learning process can be fulfilled properly.

\section{METHOD}

This study was used a model of development (Research and Development) by referring to the guidelines that have been raised by Borg and Gall in Sukmadinata (2015: 169-170) there are ten strategic step in the implementation of research and development, as follows: 1) Research and data collection; (2) Planning; (3) Development of draft product; (4) The initial field trials; (5) Revise the test results; (6) The field trials; (7) An improvement in the product field test results; (8) Test the implementation of the field; (9) refinement of the final product; (10) Disemenasi and implementation.

Each researcher or developer can pick and choose the appropriate measures to be applied, but not out of the existing order in the process of development research. Adaptation in development research is done to adjust the state of the pitch, constraints of time, cost and effort, which in this development more emphasis on the application of exceptional education and research subjects are students with special needs.

The results of the model adaptation Borg and Gall contains steps that quick and simple implementation. Steps adaptation used in the study are: (1) research and information collection (2) Planning (3) the development of the design of the initial product (4) validation of the initial product (5) The revision of the initial product (6) small group trial (7) revision of the final product and development outcomes.

This adaptation is done through a two-stage test, trial design baseline by validation of the experts involved in the development and field testing was conducted by a small group trial. The end result of this development study is to produce a product in the form of interactive multimedia materials emergency stretcher in extracurricular activities Scouting for students with hearing impairment in SMALB BC Kepanjen as a learning medium exceptional education teachers in implementing the learning process.

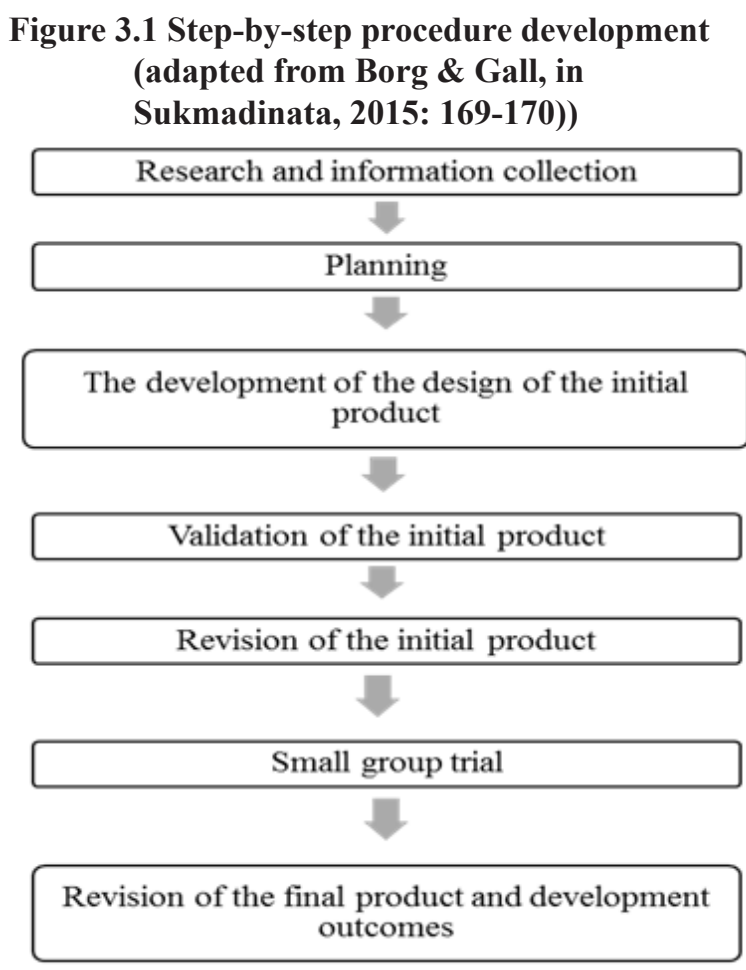

This interactive multimedia products will be tested on a limited basis to students with hearing impairment in SMALB BC Kepanjen. Design of interactive multimedia product trials on the material to make an emergency stretcher in this study will be done in three steps, as follows: Validation of subject matter experts, media experts and practitioners, small group trial. 
Subject trials in this development is the subject matter experts, media experts and practitioners and students.

The data used in the development of interactive multimedia Scouting in extracurricular activities in the form of qualitative and quantitative data. The qualitative data relating to the characteristics and nature of the product, for example, good, less good, and not good. The quantitative data in the form of percentage of respondents about the validity of the products obtained from the questionnaire score while testing the product. Data collection instruments used in interactive multimedia development research on Scouting material using interactive multimedia testing and marking sheet in the form of the instrument. Data analysis techniques used in the development of the evaluation and testing of the products are qualitative and quantitative data.

Analysis of product validation is test materials experts, media expert test, test practitioners (teachers), and a small group test (the student). Percentage data validation experts and practitioners put into quantitative data as reference took the decision to revise the product. The evaluation criteria for the percentage data for validation of product that uses an adaptation of Arikunto and Jabar qualifications (2014: 35).

Table 1. Qualification Criteria Rating Product Validation

\begin{tabular}{lcll}
\hline No & Percentage & Description & \multicolumn{1}{c}{ Criteria } \\
\hline 1 & $81 \%-100 \%$ & Very high & Very Worthy \\
2 & $61 \%-80 \%$ & High & Worth \\
3 & $41 \%-60 \%$ & Less High & Decent Revision \\
4 & $21 \%-40 \%$ & Low & Unfit \\
5 & $0 \%-20 \%$ & Very Low & Very Unfit \\
\hline
\end{tabular}

Demonstrated the feasibility of the development of interactive multimedia based Complete Standard Minimum (SKM) deaf students in BC SMALB Kepanjen in doing extracurricular activities Scouting. The assessment criteria are based product test data with the following criteria:

$$
\mathrm{N}=\frac{\text { Nilai } 1+N \text { Nlai } 2 \text { Nilai } 1+\text { Nilai } 2}{2}
$$

Subject to the small group trial was calculated using the formula diadapatasi of Sudjana in Indrawati (2014) as follows:

$$
P=\frac{\sum X}{\sum X i} \mathrm{X} 100 \% P=\frac{\sum X}{\sum X i} \mathrm{X} 100 \%
$$

To determine the conclusions that have been reached, the success rate specified criteria adapted from Arikunto-Jabar (2013: 35), as follows:
Table 2. Analysis Percentage of Subjects Evaluation Trial Small Group

\begin{tabular}{clll}
\hline No & Percentage & Description & \multicolumn{1}{c}{ Criteria } \\
\hline 1 & $81-100 \%$ & Very High & Very Effective \\
2 & $61-80 \%$ & High & Effective \\
3 & $41-60 \%$ & High Enough & Less effective \\
4 & $21-40 \%$ & Low & Ineffective \\
5 & $<21 \%$ & Very Low & Very ineffective \\
\hline
\end{tabular}

\section{FINDINGS AND DISCUSSION}

\section{Findings}

This interactive multimedia development products using three-validator, which media experts, subject matter experts and practitioners. The data collection technique using a validator validation of the questionnaire contains statements and suggestions regarding the product to be made and the validation results will serve as the basis for the revision of the products that will be developed into products before the start and continued with small group trial.

Table 3. Results of Validation Experts and Practitioners

\begin{tabular}{llcl}
\hline No & Validator & $\begin{array}{c}\text { Skor / } \\
\text { Percentage }\end{array}$ & $\begin{array}{l}\text { Score } \\
\text { Average / } \\
\text { Percentage }\end{array}$ \\
\hline 1 & Expert Matter 1 & $94 / 94 \%$ & $91 / 91 \%$ \\
2 & Expert Matter 2 & $88 / 88 \%$ & \\
3 & Expert Media 1 & $98 / 98 \%$ & $98 / 98 \%$ \\
4 & Expert Media 2 & $98 / 98 \%$ & \\
5 & Practitioners 1 & $84 / 84 \%$ & $84,5 / 84,5 \%$ \\
6 & Practitioners 2 & $85 / 85 \%$ & \\
\hline
\end{tabular}

Based on data from the validation results of two subject matter experts, obtained total score of validity for the 94 subject matter experts (94\%) and 88 (88\%) to score the validity of the two materials experts, with the average value of $91(91 \%)$. This amount meets the criteria score validity of material very decent, which is between a score of 81-100 or with a percentage of $81 \%$ - $100 \%$. Data validation results of two media experts, obtained total score of validity for a media expert 98 (98\%) and 98 (98\%) to score the validity of the two media experts, with an average score of 98 (98\%). This amount meets the criteria score validity media very decent, which is between score $81-100$ or with a percentage of $81 \%-100 \%$.

Data validation results of two practitioners, obtained total score of validity for practitioners of the $84(84 \%)$ and $85(85 \%)$ to score the validity of two practitioners, with an average value of 84.5 (84.5\%). This amount meets the criteria score validity media very decent, which is between score $81-100$ or with a percentage of $81 \%-100 \%$. 
Data from small group trial that has been conducted by the evaluation of student learning then precentage, the data can be described as follows:

Table 4. Trial Data Presentation Small Group (Problem Evaluation)

\begin{tabular}{lccccc}
\hline \multirow{2}{*}{ No } & \multirow{2}{*}{ Name } & \multicolumn{2}{c}{ Scor/ Stages } & \multicolumn{2}{c}{ Value / Stages } \\
\cline { 3 - 6 } & & I & II & I & II \\
\hline 1. & AM & 10 & 8 & 100 & 80 \\
2. & FJ & 9 & 7 & 90 & 70 \\
3. & FS & 9 & 7 & 90 & 70 \\
4. & SM & 9 & 8 & 90 & 80 \\
5. & YN & 10 & 7 & 100 & 70 \\
\hline
\end{tabular}

Table 5. Trial Data Presentation Small Group (Practice)

\begin{tabular}{lccccc}
\hline \multirow{2}{*}{ No } & \multirow{2}{*}{ Nama } & \multicolumn{2}{c}{ Scor/ Stages } & \multicolumn{2}{c}{ Value / Stages } \\
\cline { 3 - 6 } & & I & II & I & II \\
\hline 1. & AM & 26 & 24 & 86 & 80 \\
2. & FJ & 27 & 24 & 90 & 80 \\
3. & FS & 26 & 23 & 86 & 76 \\
4. & SM & 25 & 23 & 83 & 76 \\
5. & YN & 25 & 23 & 83 & 76 \\
\hline
\end{tabular}

Information:

Phase I: Learning with the help and guidance of teachers / coaches

Phase II: Learning without the help and guidance of teachers / coaches

Table 6. Trial Data Presentation Small Group Association (Problem Evaluation and Training) Phase 1

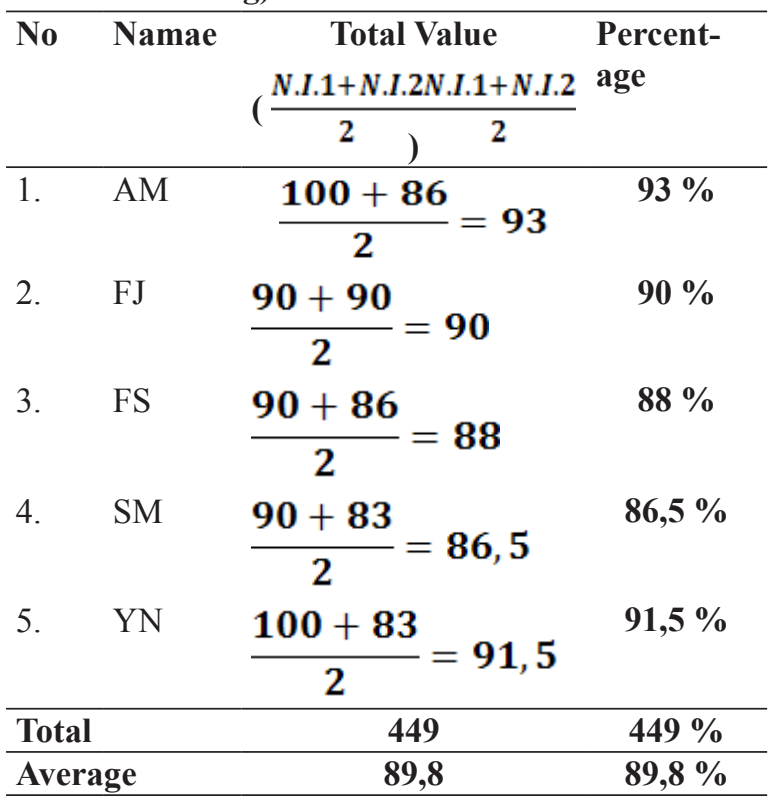

Table 7. Trial Data Presentation Small Group Association (Problem Evaluation and Training) Phase 2

\begin{tabular}{|c|c|c|c|}
\hline No & Name & $\begin{array}{c}\text { Total Value } \\
\left(\frac{N . I I .1+N . I I .2}{2}\right. \\
\left.\frac{N . I I .1+N . I I .2}{2}\right)\end{array}$ & $\begin{array}{l}\text { Per- } \\
\text { cent- } \\
\text { age }\end{array}$ \\
\hline 1. & $\mathrm{AM}$ & $\frac{80+80}{2}=80$ & $80 \%$ \\
\hline 2. & FJ & $\frac{70+80}{2}=75$ & $75 \%$ \\
\hline 3. & $\mathrm{FS}$ & $\frac{70+76}{2}=73$ & $73 \%$ \\
\hline 4. & $\mathrm{SM}$ & $\frac{80+76}{2}=78$ & $78 \%$ \\
\hline 5. & $\mathrm{YN}$ & $\frac{70+76}{2}=73$ & $73 \%$ \\
\hline \multicolumn{2}{|c|}{ Total } & 379 & $379 \%$ \\
\hline \multicolumn{2}{|c|}{ Average } & 75,8 & $75,8 \%$ \\
\hline
\end{tabular}

Data from the trial results of small groups, divided into two phases, phase I and phase II. Phase I is learning with the help and guidance of teachers or coaches, obtained total score validity of phase I, 449 (449\%), with an average value of 89.8 (89.8\%). Data from the trial results of small groups for the second phase, learning without the help and guidance of teachers or coaches, obtained total score validity of phase II, 379 (379\%), with an average value of 75.8 (75.8\%). Phase I, showed a higher percentage compared to the second phase, $89.8 \%$, with the criteria of highly effective, whereas the second phase, showed a lower percentage, $75.8 \%$, the effective criteria.

\section{Discussion}

Implementation of students with hearing impairment learning not only use books and simple media, necessary media capable of supporting all aspects of the development of students with hearing impairment. The word comes from the Latin media, medius, which literally means "middle", "intermediate", or "introduction". In the Arabic language support, media is an intermediary or an introductory message from the sender to the receiver (Arsyad, 2014: 3). Based on the above understanding if some media that carry messages or information that aims instructional 
or meaning or purpose of teaching the media is called a medium of learning.

Gerlach and Ely (1971 in Arsyad (2014:12) presents three characteristics of the media, namely: a) the characteristics fixative (fixative property), b) characteristic of manipulative (Manipulative property), and c) Characteristics Distributive (Distributive Property), Instructional media have functions that are quite diverse in supporting the teaching and learning process. According to Levie and Lentz in Arsyad (2014: 20) suggests four instructional media functions, as follows: a) the function of attention, b) affective function, c) cognitive function, and d) compensatory function.

Medium of learning, besides there are the characteristics and functions of media, there are also important, namely the selection criteria for instructional media. According Arsyad (2014:75) "media selection criteria derived from the concept that the media are part of the instructional system as a whole". To that end, some of the criteria that should be considered in selecting the media, namely: a) in accordance with the objectives to be achieved, b) Right to support the subject content, and c) Practical, Lues and survive, d) skilled teachers to use, e) the classification of the target, f) technical quality.

Multimedia, has four essential components, first there must be computers that coordinate what will be seen and heard, and interact with us. Secondly there must be a link that connects us with the information. Thirdly, there should be a navigation tool that guides us, exploring the network of interconnected information. Fourth, multimedia provides a place for us to collect, process, and consume information and ideas of our own.

According to the dictionary, computer and interactive technology is the ability of a system or program that can ask something (held a question and answer), then take action based on those responses. While interactive learning media is a media that is equipped with a controller that can be operated by the user, so the user can choose what the user want for the next process. From the above understanding can be concluded that an interactive media say if it can communicate and interact with its users so that users can give commands that will be run by the media.

The advantages of interactive multimedia by Sarwiko, (2010:3) are as follows: a) The learning system is more innovative and interactive, b) teaching will always be required to be creative innovative in seeking a breakthrough learning, c) is able to combine text, images audio, music, animated images or video in a union of mutual support in order to achieve the learning objectives, d) increase the motivation of learners during the learning process to obtain the desired objectives, e) being able to visualize the material which has been difficult to be explained merely by an explanation or props conventional , f) train learners in getting more independent in science.

In this material, students with hearing impairment, cognitive will be taught about emergency stretchers, from introduction or understanding, usability, making materials and how to make. Affectively, deaf students are taught attitudes help each other and others in a state of emergency and able to work in a team, especially in making an emergency stretcher. In psychomotor, deaf students were able to be trained to developed expertise in a skill area, in this case make a knot or a bond.

Stretcher also called dragbar, its usefulness to move or lift the victim from the scene or accident to a safer place. Stretcher is a tool created to evacuate casualties from the scene to the place that is safer or point of reference (hospital, clinic, or a safe place for victims) (Soedrajat, nd).

Based on data from the validation results of two subject matter experts, with an average value of 91 $(91 \%)$. This amount meets the criteria score validity of material very decent, which is between a score of $81-100(81 \%-100 \%)$. This indicates that the interactive multimedia material emergency stretcher in extracurricular activities Scouting is very feasible to use without revision. Based on data from the validation results of two media experts, with an average score of $98(98 \%)$. This amount meets the criteria score validity media very decent, which is between score $81-100(81 \%-100 \%)$. This indicates that the interactive multimedia material emergency stretcher in extracurricular activities Scouting is very feasible to use without revision.

Based on data from the validation results of two practitioners, with an average value of 84.5 (84.5\%). This amount meets the criteria of validity are very decent score, which is between a score of $81-100(81 \%$ - 100\%). This indicates that the interactive multimedia material emergency stretcher in extracurricular activities Scouting is very feasible to use without revision.

Data from the trial results of small groups, divided into two phases, phase I and phase II. Phase I is learning with the help and guidance of teachers or coaches, obtained total score validity of phase I, $449(449 \%)$, with an average value of $89.8(89.8 \%)$. This amount meets the criteria of validity score highly effective, ie between the score of $81-100(81 \%$ $100 \%)$. This indicates that the interactive multimedia material emergency stretcher in extracurricular activities Scouting effectively utilized for deaf students in learning.

Based on the data from the trial results of small groups for the second phase, ie learning without the 
help and guidance of teachers or coaches, obtained total score validity of phase II, 379 (379\%), with an average value of $75.8(75.8 \%)$, This amount meets the criteria score validity effective, ie between the scores $61-80(61 \%-80 \%)$. This indicates that the interactive multimedia material emergency stretcher in extracurricular activities Scouting effective for use in deaf students in learning.

Based on data from the results of a small group trial, Phase I, showed a higher percentage compared to the second phase, ie $89.8 \%$, with the criteria of highly effective, whereas the second phase, showed a lower percentage, namely $75.8 \%$, with effective criteria. From these data, it can be concluded that learning with the help and guidance of teachers or coaches are very effective for use in learning using interactive multimedia. However, the interactive multimedia learning without the help and guidance of teachers or supervisors still fall into the category effective for use.

Products developed in the form of computer software has advantages as follows: 1) students are more enthusiastic and interested in the learning process, because the presentation is equipped with a background of menu options, animations, images and video that can interact with the user so that the user is able to control and choose what the wishes of users, 2) it is easier to learn, since learning media is equipped with a selection of materials that will be studied in accordance with the wishes of users, 3) the product is very practical and efficient to use because the file size is relatively small and very easy to duplicate in the interests education, especially in the education learning is outstanding.

Product development of instructional media in the form of interactive multimedia can be helpful in the learning process, according to Sudjana and Rival in Arsyad (2014:28) as follows, learning will be more attracted the attention of students so as to foster motivation to learn, learning materials will be quite vague so it can be better understood by students and enable it to master and achieve learning objectives, instructional methods will be more varied, not solely verbal communication through the narrative of words by the teacher, so that students do not get bored and teachers are not exhausted especially if teachers teach at any hour of the lesson, students can more learning activities because not only listen to the description of the teacher, but also other activities such as observing, doing, demonstrating, acting and others.

The products developed have a positive impact in the learning process, in Arsyad (2014:25) as follows: (1) Submission of the lessons become more standardized, (2) learning can be more attractive, (3) learning to be more interactive, (4) long learning time required can be shortened, (5) the quality of learning outcomes can be improved, (6) the learning can be given when and where desired and needed, (7) the positive attitude of students towards what they are learning and the learning process can be improved, (8) the teacher's role may be changed to a more positive direction.

The product developed has the disadvantage that it also should be noted that, if the product is used in other schools that do not have the means in the form of a computer or laptop, then the learning process by using this media can not be implemented. In addition to these shortcomings, this product also has advantages, among others; (1) is able to create interactive multimedia learning process viable and effective has been through the validation of experts and practitioners. (2) an interactive learning media can be used as an alternative teachers in particular learning materials emergency stretcher in extracurricular activities Scouting.

\section{CONCLUSION AND SUGGESTION}

Interactive multimedia product material emergency stretcher is multimedia that is tailored to the characteristics of students with hearing impairment. This interactive multimedia made as attractive and simple as possible so it is easy to use and understandable by students with hearing impairment. Interactive multimedia is made using materials such as reading text, images, animation and video. This is done to be able to provide traction and interest in learning for students with hearing impairment as well as facilitate the process of understanding the material. The results of product development in the form of interactive multimedia material contains about emergency stretchers. This product is packaged in a CD (compact disc) or in the form of more storage and comes with an instruction manual.

There are suggestions in the development of the dissemination of advice and suggestions of further development. Suggestions dissemination, before reproduced and distributed to a broader scope, this product should be prepared and validated in accordance with the target to be addressed and adjusted to the curriculum in force. In order for the development of interactive multimedia can be used on a wider scope needs to be done further research and development with respect to the development of research step 4-10 to correspond to the steps of the Borg and Gall. The need for socialization at school that will be using this product.

Product development efforts is towards more, researchers gave suggestions as follows: further research can be done through quantitative research to test the effectiveness of the use of interactive multimedia materials stretcher emergency in extracurricular activities Scouting for students with hearing impairment grade X, XI, and XII to increase students' learning ability independently. The subject of research should be conducted on the subject more widely, both students and schools are used as small group trial, in order that these products really useful and well utilized. 


\section{REFERENCES}

Arikunto, S. 2013. Prosedur Penelitian: Suatu Pendekatan Praktik. Jakarta: Rineka Cipta.

Arikunto, S. \& Jabar, C.S.A. 2014. Evaluasi Program Pendidikan: Pedoman Praktis bagi Mahasiswa dan Praktisi Pendidikan. Jakarta: Bumi Aksara.

Arsyad, A. 2014. Media Pembelajaran. Jakarta: Raja Grafindo Persada.

Efendi, M. 2009. Pengantar Psikopedagogik Anak Berkelainan. Jakarta: PT. Bumi Aksara.

Indrawati, R. D. 2014. Pengembangan Buku Panduan Pengemasan Sayur Organik bagi Siswa Tunagrahita Ringan SMALB di SLB PTN Bagian $C$ Lawang. Skripsi. Malang: FIP UM.

Peraturan Menteri Pendidikan dan Kebudayaan Republik Indonesia Nomor 81A Tahun 2013 Tentang Implementasi Kurikulum.
Sarwiko, D. 2010. Pengembangan media pembelajaran berbasis multimedia interaktif menggunakan macromedia director $m x$ (studi kasus mata kuliah pengolahan citra pada jurusan s1 sistem informasi). (Online) http://www.gunadarma.ac.id/ library/articles/graduate/computer-science/2010/ Artikel_10105507.pdf. diakses pada 26 Februari 2016.

Somantri, S. 2012. Psikologi Anak Luar Biasa. Bandung: Refika Aditama.

Soedrajat. Tanpa tahun. Tandu Darurat. (Online) http:// ajtratnabudakbager.blogspot.co.id/p/tandu.html. Diakses pada 11 Maret 2016.

Sukmadinata, N. S. 2015. Metode Penelitian Pendidikan. Bandung: PT Remaja Rosdakarya. 